\section{References}

1. Tripathi AK, Shukla A, Mishra S, Yadav YS, Yadav DK. Eltrombopag therapy in newly diagnosed steroid non-responsive ITP patients. Int J Hematol 2014;99:413-417.

2. Luzzatto L, Seneca E. G6PD deficiency: a classic example of pharmacogenetics with on-going clinical implications. Br J Haematol 2014;164:469-480.
3. No authors listed. Glucose-6-phosphate dehydrogenase deficiency. WHO Working Group. Bull World Health Organ 1989;67:601-611.

4. Cappellini MD, Fiorelli G. Glucose-6-phosphate dehydrogenase deficiency. Lancet 2008;371:64-74.

5. van de Mheen L, Smits SM, Terpstra WE, Leyte A, Bekedam DJ, van den Akker ES. Haemolytic anaemia after nitrofurantoin treatment in a pregnant woman with G6PD deficiency. BMJ Case Rep 2014:2014.

\title{
Wernicke's Encephalopathy in an Acute Myeloid Leukemia Patient: A Case Study
}

\author{
Bir Akut Myeloid Lösemi Hastasında Wernicke Ensefalopatisi: Bir Olgu Sunumu
}

\author{
Muhammet Maden1, Gülsüm Pamuk1, Yahya Çelik2, Ercüment Ünlü3 \\ 1Trakya University Faculty of Medicine, Department of Hematology, Edirne, Turkey \\ 2 Trakya University Faculty of Medicine, Department of Neurology, Edirne, Turkey \\ ${ }^{3}$ Trakya University Faculty of Medicine, Department of Radiodiagnostics, Edirne, Turkey
}

To the Editor,

Wernicke's encephalopathy (WE) is a life-threatening disease with acute onset, resulting from thiamine deficiency. Causes are alcohol intake, malnutrition, gastric bypass surgery, human immunodeficiency virus infection, total parenteral nutrition (TPN), chronic dialysis, and cancer [1]. WE may cause neurological symptoms such as nystagmus, ophthalmoplegia, ataxia, confusion, convulsions, delirium, coma, and acute psychoses [2].

An 18-year-old female patient with refractory acute myeloid leukemia (AML) was given FLAG-IDA (fludarabine, cytosine arabinoside, idarubicin) chemotherapy protocol. As she developed typhlitis, oral intake was stopped; broad-spectrum antibiotics and TPN without any vitamin supplementation were started. She developed a fixed look to a point, chin and upper extremity spasms, and urinary incontinence on the $38^{\text {th }}$ day of chemotherapy. Neurological examination showed nonlateralization, bilateral light reflexes were $+/+$, verbal stimuli were negative, and the reflex response to painful stimuli was positive. Laboratory results showed hemoglobin of $7.2 \mathrm{~g} / \mathrm{dL}$, leukocytes of $3380 / \mathrm{mm}^{3}$, neutrophils of $2890 / \mathrm{mm}^{3}$, platelets of $48,000 / \mathrm{mm}^{3}$, and normal blood biochemistry. The level of serum thiamine could not be measured, because the laboratory did not have the capabilities to measure it. Brain diffusion MRI showed increased signal intensity in the medial thalami (Figure 1). The patient was diagnosed with WE. She was given 1500 mg/day thiamine i.v. for 3 days and $250 \mathrm{mg} /$ day thiamine i.v. for another 5 days. On the fourth day of thiamine infusion, her general condition began to improve and she started giving one-word responses to verbal stimuli. Her convulsions disappeared and she started to form short sentences and walk without assistance; she was discharged on the $30^{\text {th }}$ day of thiamine replacement therapy. Currently, 2 years have passed since the WE and the patient is in complete hematologic remission.

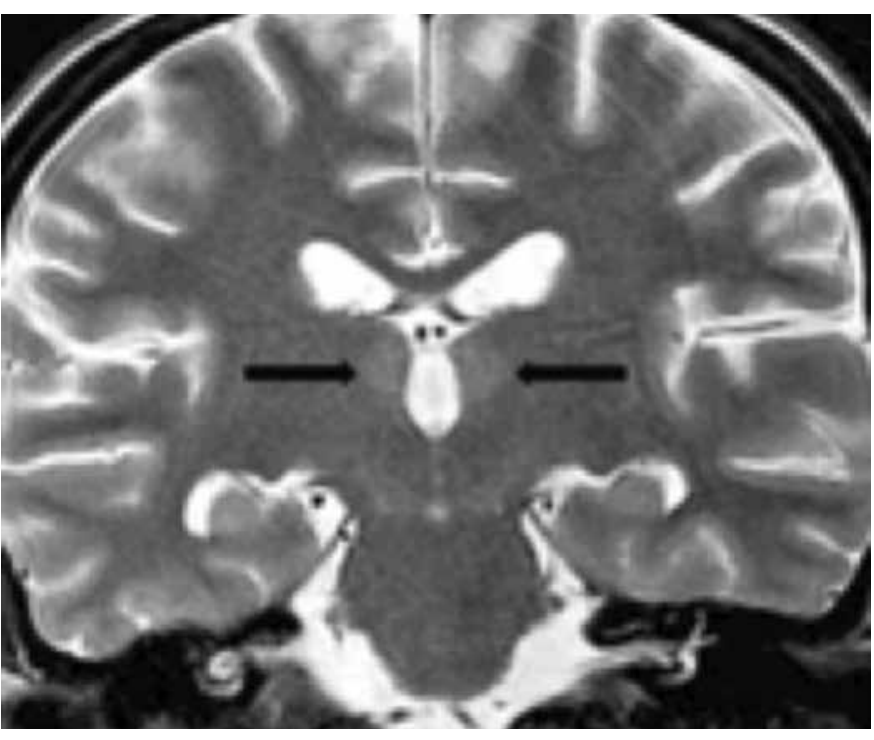

Figure 1. Coronal T2-weighted image shows symmetrical, weak, and limited increased signal intensity in the medial thalami and in the third ventricle-facing surface. 
In cancer patients, WE may develop because of certain chemotherapeutic agents (especially doxifluridine, ifosfamide, and 5-fluorouracil) [3], malnutrition, and thiamine depletion due to fast-growing tumor cells or gastrointestinal bypass surgery [2]. In the literature, there are a few cases of WE in AML. The diagnosis of WE in cancer patients is difficult because there are many causes of similar symptoms, such as confusion-causing hypoxia, infections, electrolyte imbalance, opioid medications, chemotherapy, brain and meningeal metastases, and delirium [4]. To make a definite diagnosis of WE, it should be clinically suspected. WE may be verified with the measurement of thiamine concentration in blood or erythrocyte transketolase activity; however, these tests are not widely available [3]. Magnetic resonance imaging (MRI) has 93\% specificity and $53 \%$ sensitivity to verify the diagnosis [2]. Bilateral dorsomedial thalamus, tectal plaque, and periaqueductal gray matter signal abnormalities are observed as classical in MRI [5]. WE should be treated empirically with $500 \mathrm{mg}$ of thiamine 3 times per day for 2-3 days. If there is no response, supplementation may be discontinued after 2-3 days. In case an effective response is observed, $250 \mathrm{mg}$ of thiamine should be continued daily until clinical improvement [2].

Thiamine supplementation should definitely be added to TPN or the diets of hematologic malignancy patients with poor oral nutrition. When symptoms such as ataxia, confusion, or ophthalmoplegia appear in these patients, brain MRI should be immediately performed and thiamine infusion should be initiated immediately in the case of strong suspicion.

Keywords: Thiamine, Wernicke's encephalopathy, Acute myeloid leukemia
Anahtar Sözcükler: Tiamin, Wernicke ensefalopatisi, Akut myeloid lösemi

\section{Authorship Contributions}

Concept: Muhammet Maden, Gülsüm Pamuk, Design: Muhammet Maden, Gülsüm Pamuk, Data Collection or Processing: Muhammet Maden, Ercüment Ünlü, Yahya Çelik, Analysis or Interpretation: Muhammet Maden, Gülsüm Pamuk, Ercüment Ünlü, Yahya Çelik, Literature Search: Muhammet Maden, Gülsüm Pamuk, Writing: Muhammet Maden.

Conflict of Interest: The authors of this paper have no conflicts of interest, including specific financial interests, relationships, and/or affiliations relevant to the subject matter or materials included.

\section{References}

1. Papila B, Yildiz O, Tural D, Delil S, Hasiloglu ZI, Ayan F, Papila C. Wernicke's encephalopathy in colon cancer. Case Rep Oncol 2010;3:362-367.

2. Sechi G, Serra A. Wernicke's encephalopathy: new clinical settings and recent advances in diagnosis and management. Lancet Neurol 2007;6:442455.

3. Basu TK, Dickerson JW. The thiamin status of early cancer patients with particular reference to those with breast and bronchial carcinomas. Oncology 1976;33:250-252.

4. Kuo SH, Debnam JM, Fuller GN, de Groot J. Wernicke's encephalopathy: an underrecognized and reversible cause of confusional state in cancer patients. Oncology 2009;76:10-18.

5. Zuccoli G, Siddiqui N, Bailey A, Bartoletti SC. Neuroimaging findings in pediatric Wernicke encephalopathy: a review. Neuroradiology 2010;52:523-529.

\title{
Kaleidoscopic Views in the Bone Marrow: Oxalate Crystals in a Patient Presenting with Bicytopenia
}

Kemik Iliğinde Oksalat Kristalleri Birikimine Bağlı Gelişen Bisitopeni

\author{
Yelda Dere1, Simge Erbil2, Murat Sezak22, Başak Doğanavşargil2, Mümtaz Yılmaz³, Nazan Özsan², Mine Hekimgil2 \\ 1Sıtkı Koçman University Faculty of Medicine, Department of Pathology, Muğla, Turkey \\ 2Ege University Faculty of Medicine, Department of Pathology, Izmir, Turkey \\ ${ }^{3}$ Ege University Faculty of Medicine, Department of Nephrology, Izmir, Turkey
}

To the Editor,

Our patient is a 24-year-old female who was admitted to the nephrology clinic of our hospital with fatigue, weakness, and swelling of the feet. From her medical history, we learned that she had two operations for nephrolithiasis at the ages of 9 and
12, and she underwent renal transplantation in 2013, but she was still on hemodialysis. Laboratory tests showed bicytopenia (anemia and leukopenia) with hemoglobin of $8.2 \mathrm{~g} / \mathrm{dL}$ and white blood cell count of $3800 / \mathrm{mm}^{3}$, and she underwent a bone marrow (BM) biopsy. Microscopically, an almost complete suppression of 